\title{
QUEEN'S
UNIVERSITY
BELFAST
}

\section{Deconstructing Victim and offender Identities in Discourses on Child Sexual Abuse: Hierarchies, Blame and the Good/Evil Dialectic}

McAlinden, A-M. (2014). Deconstructing Victim and offender Identities in Discourses on Child Sexual Abuse: Hierarchies, Blame and the Good/Evil Dialectic. British Journal of Criminology, 54(2), 180-198.

https://doi.org/10.1093/bjc/azt070

\section{Published in:}

British Journal of Criminology

\section{Document Version:}

Peer reviewed version

Queen's University Belfast - Research Portal:

Link to publication record in Queen's University Belfast Research Portal

\section{Publisher rights}

(c) The Author 2014. Published by Oxford University Press on behalf of the Centre for Crime and Justice Studies

This is a pre-copyedited, author-produced PDF of an article accepted for publication in The British Journal of Criminology following peer review. The version of record McAlinden, A-M 2014, 'Deconstructing Victim and Offender Identities on Discourses on Child Sexual Abuse: Hierachies, Blame and the Good/Evil Dialectic: Hierachies, Blame and the Good/Evil Dialectic' British Journal of Criminology, vol 54, no. 2 , pp. 180-198 is available online at: http://bjc.oxfordjournals.org/content/54/2/180.

\section{General rights}

Copyright for the publications made accessible via the Queen's University Belfast Research Portal is retained by the author(s) and / or other copyright owners and it is a condition of accessing these publications that users recognise and abide by the legal requirements associated with these rights.

Take down policy

The Research Portal is Queen's institutional repository that provides access to Queen's research output. Every effort has been made to ensure that content in the Research Portal does not infringe any person's rights, or applicable UK laws. If you discover content in the Research Portal that you believe breaches copyright or violates any law, please contact openaccess@qub.ac.uk. 
FINAL AUTHOR VERSION

Published version: British Journal of Criminology (2014), 54(2):180-198

DECONSTRUCTING VICTIM AND OFFENDER IDENTITIES
IN DISCOURSES ON CHILD SEXUAL ABUSE:
HIERARCHIES, BLAME AND THE GOOD/EVIL DIALECTIC

Anne-Marie McAlinden*

Contemporary social and political constructions of victimhood and offending behaviour lie at the heart of regulatory policies on child sexual abuse. Legislation is named after specific child victims of high profile cases, and a burgeoning range of pre-emptive measures are enacted to protect an amorphous class of 'all potential victims' from the risk sex offenders are seen as posing. Such policies are also heavily premised on the omnipresent predatory stranger. These constructed identities, however, are at odds with the actual identities of victims and offenders of such crimes. Drawing on a range of literatures, the core task of this article is to confront some of the complexities and tensions surrounding constructions of the victim/offender dyad within the specific context of sexual offending against children. In particular, the article argues that discourses on 'blame' - and the polarised notions of 'innocence' and 'guilt' - inform respective hierarchies of victimhood and offending concerning 'legitimate' victim and offender status. Based on these insights, the article argues for the need to move beyond such monochromatic understandings of victims and offenders of sexual crime and to reframe the politics of risk accordingly.

Key Words: Victims, Offenders, Hierarchies, Blame, Good/Evil, Sexual Crime, Risk

\section{Introduction}

In less than half a century, victims of crime have gone from being 'the forgotten actor' (Zedner, 2002: 419; see also Mawby and Walklate, 1994) of criminal justice policy to being the mainstay of political discourses on 'law and order' (Elias, 1993; Dubber, 2006). Victimcentric discourses have underpinned the contemporary regulatory regime with the co-optation of the crime victim providing 'an all-purpose justification for measures of penal repression' (Garland, 2001: 143) and a whole industry of 'offender-focused corrections' (McEvoy and McConnachie, 2012: 530, citing Rock, 1998). Other scholars have explored what has been termed 'the politics of victimhood' (Bouris, 2007: 10) within the context of peace making or

\footnotetext{
* Anne-Marie McAlinden, Reader in Law, School of Law, Queen's University Belfast, 29 University Square, Belfast, BT7 1NN, UK; a.mcalinden@qub.ac.uk
} 
transitional justice (McEvoy and McConnachie, 2012). This article extends this discussion by examining the construction and reproduction of victimhood, as well as offending behaviour, within the context of risk-centric discourses concerning sex offending against children.

Legislative campaigns to enact more punitive measures against sex offenders are often named after specific child victims (McAlinden, 2012a). Measures such as 'Megan's Law' or 'Jessica's Law' in the United States or 'Sarah's Law' in the United Kingdom call for community notification and other restrictive measures on the movements of sex offenders. These 'memorial laws' (Valier, 2005) are used rhetorically to 'lever up punitiveness' (Zedner, 2002: 447) and contribute to the 'emotionalization' of discourses on crime and justice (De Haan and Loader, 2002; Karstedt, 2002). This process of law making results in what Tilly (2008: 33) has referred to as a 'double game' of credit and blame which attaches to victims and offenders. The 'politics of pity' (Aradau, 2004, cited in Walkate, 2011: 189) which emerges legitimises the suffering of certain classes of victims through mandated policy intervention. This is juxtaposed with a 'politics of vindictiveness' (Young, 2003) in which a burgeoning range of retributive measures seek to fix blame on sexual perpetrators and punish them appropriately.

There are also concomitant claims of the need for protection of an undifferentiated and abstract class of generic or potential victims as 'vulnerable citizens' (Ramsay, 2010). Regulatory policies on sexual crime have been one of the primary targets of "precautionary logic' (Ericson, 2007) underpinning reactionary risk-averse policies to crime or other threats to social order (Crawford, 2003; Loader and Walker, 2007). Pre-emptive approaches to 'risk' seek to govern 'worst case scenarios' and prevent all possible manifestations of future harm to potential victims before they occur (Zedner, 2009). Sex offenders against children are 
singled out as meriting 'extra-legal' punishment because of the ubiquitous risk they are seen as presenting (Pratt, 2000). This 'differential justice' (Weaver and McNeill, 2010: 274) has manifested itself in a policy of 'radical prevention' (Hebenton and Seddon, 2009: 2) with sexual offenders via preventive detention and restrictions placed on dangerous offenders in the community. Key policy developments within the United Kingdom, for example, include multi-agency panels to assess and manage risk (Kemshall and Maguire, 2001) and a host of regulatory mechanisms such as notification ${ }^{1}$ and pre-employment vetting and barring (McAlinden, 2010). ${ }^{2}$ Most notably perhaps, the enactment of the offence of 'meeting a child following sexual grooming etc' ${ }^{3}$ seeks to encapsulate potential 'risk' by criminalising the preparatory behaviour before actual abuse or harm occurs (McAlinden, 2012b).

Donoghue (2013) and others have underlined the traditional dominance of polity in acting as primary definers of accepted knowledge and understanding of victimhood and vulnerability. In relation to sexual offending against children, however, this constitutes only part of the narrative. Hierarchical understandings of what constitutes legitimate victim or offender status and the related juxtaposition of 'good' and 'evil' which attaches to the innocence or blameworthiness of individual victims and offenders appear to permeate both popular and official discourses on sexual crime. What Walklate (2007) has called 'imagined victims', and by extension what could be deemed 'imagined offenders', can similarly be discerned in the institutional allocation of blame and in the process of 'othering' concerning sexual offending against children. It is the institutionalisation of blame via scientific and legal processes of blame allocation which reproduces and reinforces the popular bifurcation of those deemed 'innocent' and 'blameworthy', further legitimising punishment.

\footnotetext{
${ }^{1}$ Sexual Offences Act 2003, Part 2.

${ }^{2}$ See the Safeguarding Vulnerable Groups Act 2006 now scaled back under the Protection of Freedoms Act 2012, Part V.

${ }^{3}$ Sexual Offences Act 2003, s 15.
} 
Punitive policy making discourses engage victims and offenders in a 'zero-sum game' (O'Malley, 2004: 323) where it is assumed that the rights of the former can only be upheld at the expense and exclusion of those of the latter (see also Garland, 2001; Dubber, 2006). As McEvoy and McConnachie (2012: 527, 530) note in the transitional justice context, victims' rights or needs 'become intrinsically linked to the punishment of perpetrators' and 'punishing the wicked [becomes] the most satisfying method of honouring the righteous victim.' This also accords with Brewer's (2010) notion of 'public victimhood' wherein certain dominant voices are utilised politically to spear head the neo-liberal agenda. In utilising 'victims in the service of severity' (Ashworth, 2000: 186), however, no attempt is made to delineate clearly who are victims of sexual crime?; what are their individual as well as collective interests, rights and needs?; and how do these relate to, or differ from, those of offenders? There is an underlying assumption it seems, as O'Malley (2004: 323) has contended that 'diverse configurations of risk can be collapsed into a single category.' As others have argued in the context of debates on international sentencing, and access to justice and rights for victims, there is a need, however, 'to progress beyond partisan ideology, rhetorical symbolism and the dynamics of retribution and vindictiveness' (Henham, 2004: 27).

Victims are often perceived as 'the mirror' or 'binary opposite' (Rock, 1998: 195; McEvoy and McConnachie, 2012: 527-28) of perpetrators of sexual crime. What Rock (1998: 195) terms the 'indissoluble dialectic' is predicated on the young, 'innocent' and unsuspecting target who represents the 'antithesis' (Merleau-Ponty, 1973: 31, cited in Rock, 1998) of the older, adult, predatory male 'monster' who was previously unknown to them. Indeed, while many of the scholars cited above (e.g. Ashworth, and Garland) have noted the symbolic instrumentalisation of victims in order to advance the neo-liberal agenda, not all victims or 
offenders of sexual crime hold the same level of newsworthiness and interest for the media or politicians and some are more appealing than others. Further, victim or offender status is not fixed but rather subject to change over time. Thus, a potentially richer and much more interesting narrative emerges concerning the politics of victimhood and offenderhood than is traditionally suggested.

The core task of this article is to confront some of these complexities and tensions surrounding constructions of the victim/offender dyad within the specific problem field of sexual offending against children. In so doing, the article assumes a dual focus: constructions of blame and blamelessness concerning victims and offenders of child sexual abuse as well as the complexities concerning the victim/offender divide. In relation to the former, it will be argued that there is a fundamental dissonance between much of the constructed identities of victims and offenders of such crimes and the actual identities of offenders and the lived experiences of victims. Drawing on a range of literatures, including victimology, transitional justice, feminist criminology as well as sex offending specifically, the article argues in particular that discourses on 'blame' and the related oppositional notions of 'innocence'/'good' and 'guilt'/'evil' - shape and inform respective hierarchies of victimhood and offending concerning 'legitimate' victim and offender status. Such siloed versions of victimhood and offending behaviour may combine to form a 'hierarchy of blame' which cannot easily accommodate 'deviant' victims or 'vulnerable' offenders who lie in the middle ground between the polarities of accepted victim and offender status. Indeed, in relation to the latter, the article also critically explores the ways in which victims and perpetrators of child sexual abuse are represented as a false dichotomy as they are not always easily identifiable as distinct, mutually exclusive or indeed fixed entities. Rather, given the fluidity of these categories in many instances, the article makes the case for overcoming these 
artificial and monochromatic distinctions in order to develop more effective responses to sexual offending concerning children.

In the sections which follow the article first examines these arguments in relation to victims, hierarchies and blame, and subsequently offenders, hierarchies and blame. While there is an obvious element of overlap between them they are differentiated and unpacked here for the purposes of critical analysis. Finally, based on these insights, ultimately the article argues for the need to move beyond polarised binary constructions of victims and offenders and to reframe the politics of risk in order to meaningfully engage with the realities of victimhood and offending behaviour surrounding child sexual abuse.

\section{Victims, Hierarchies and Blame}

The generally older literature on victimology and more recent scholarship on transitional justice demonstrate that there is a 'hierarchy of victimhood' (Carrabine et al, 2004) and that “"true” victim status demands innocence' (McEvoy and McConnachie, 2012: 531-32). Within the context of sexual offending against children, this distinction between the 'good' and 'bad' victim (Madlingozi, 2007), or what Tilly (2008: 94) refers to as 'the worthy sufferers and the unworthy remainder', is perhaps even more pronounced. As Walkate (2011) has shown, knowledge and understanding of victimhood and victimisation (generally referred to as the processes associated with becoming a victim) are firmly rooted in conceptions of vulnerability. Within what Furedi (2013: 56) terms 'the master-frame of victimisation', the 'ideal' (Christie, 1986: 18) or 'imagined' victim (Walkate, 2007) of child sexual abuse is based on perceived notions of children's vulnerablility, innocence and their deserving of help 
(Best, 1993). The cultural power of the ideal child sexual abuse victim has become embedded in social and political understandings of children and their vulnerability in which 'the victimization of children is seen solely in terms of child abuse' (Morgan and Zedner, 1992: 5), and primarily child sexual abuse as narrowly conceived.

Several writers have highlighted the 'sacralisation' of children (Zelizer, 1994) or the 'veneration of the innocence of childhood' (Furedi, 2013: 45) as the bedrock of moral politics of late modernity. The innocence of children has become the symbol of purity (Hacking, 2003: 40) and an important moral conduit for the channelling of sentiments about right and wrong (Furedi, 2013: 44). As a result, 'risk anxiety' (Scott et al, 1998: 689) about children and their perceived vulnerability are presented as defining features of contemporary childhood. Extending this broad line of thinking and drawing on recent work by Sandra Walklate (2011: 180-84), I would posit that there are both inherent' or 'structural' as well as 'experiential' components which appear to underpin contemporary constructions of the vulnerability and innocence of children and the resultant hierarchy of victim legitimacy concerning child sexual abuse.

First, age in particular is a key inherent attribute informing public and political conceptualisations of children's victimhood and vulnerability. Children are regarded as intrinsically vulnerable (Furedi, 2013: 42), and therefore entirely pure or 'blameless' simply by virtue of their age or status as children. Age not only amplifies the power imbalance between the parties but serves to underline the wholesomeness of the victim and thereby the culpability and perverse nature of the offender. As Tilly (2008: 95) contends in relation to offenders, 'the younger the victim, the greater the blame.' Such axiomatic age-related distinctions between the intrinsic innocence of victims and the guilt of offenders have also 
become enshrined within the legal system (chiefly by virtue of the law on the age of consent) which acts as an 'echo chamber for conversations about credit and blame' (Tilly, 2008: 35).

Second, there are also a number of structural variables related to assumed patterns of sexual victimisation among children. The child deemed 'worthy' or 'deserving' of the status of victim will have been abused by someone with whom they had no prior relationship. By way of analogy with the literature on rape (e.g. Stewart et al, 1996; Temkin and Krahé, 2008), the 'real child abuse' stereotype usually takes place in an outdoor setting, involves the use or threat of force by a stranger perpetrator, and an unsuspecting and passive victim in a one-off random assault. These reductionist narratives concerning legitimate victimhood run counter to the available evidence in child sexual abuse cases in which the victim of aberrational extrafamilial abuse is privileged over the more vulnerable victim of intimate abuse who is abused repeatedly over a period of time. Once more, social constructions of victimhood which delegitimize the experiences and subjugate the voices of many victims are also reflected in and reinforced by law. For example, the 'counting rules' often categorise many instances of intra-familial abuse as sample counts which may be under-representative of the nature and scale of intra-familial abuse suffered by individual victims. Further, there would also appear to be a gendered dimension to contemporary constructions of childhood sexual victimisation, suggesting high levels of victimisation among girls, which goes against the grain of research demonstrating patterns of victimisation among both boys and girls. ${ }^{4}$

Indeed, who acquires the label of victim and how and when this occurs depends not only on the attributes of victims themselves but also on the reactions of others (Holstein and Miller, 1990; Rock, 2002). As Walklate (2011: 189) has argued, there is not only a hierarchy of

\footnotetext{
${ }^{4}$ For example, large scale research by Elliott et al (1995) demonstrated that $58 \%$ of sex offenders targeted girls; $14 \%$ targeted boys; while the remaining $28 \%$ targeted both boys and girls. See also Grubin (1998).
} 
victim legitimacy but also a politics associated with this legitimacy. What Walklate terms 'experiential victimization' (2011: 181) may be especially impactful in identifying or validating the status of children as child victims. Particularly 'innocent children' become the catalyst of moral politics (Hunt, 2011: 61) via 'moral panics and moral regulation' (Hunt, 2011). Stereotypical cases involving children abused or murdered by predatory sex offenders become 'signal crimes' (Innes, 2004) in shaping public attitudes about victims and offenders and in precipitating legislative and policy change (Silverman and Wilson, 2002). The 'Soham murders' of school girls Holly Wells and Jessica Chapman by school caretaker Ian Huntley led to the Bichard Inquiry (2004) and reform of the law on pre-employment vetting and barring. ${ }^{5}$ Similarly, the kidnapping and murder of eight-year old Sarah Payne by Roy Whiting in July 2000 led to the News of the World's 'Name and Shame' campaign which ultimately came to fruition with the introduction of 'Sarah's Law', allowing parents or carers to check the background of those with unsupervised access to their children. Notably, in both cases, the victims were young girls who were in a public space and engaged in the routine activities of childhood at the time of the offence (out for a walk, and playing in a field respectively) and the perpetrators were adult males with a history of sex offending. As Jacobsson and Löfmarck (2008: 204-205) have contended 'scandals provoke moral positioning' and highlight a 'moral order that is temporarily disrupted.' The depiction of the loss of innocence in such cases 'crystallized fears over the image of the predatory child sex offender' (Greer, 2007: 28). In this vein, the subsequent calls for increased surveillance and community control of sex offenders can be regarded as an attempt to restore the moral order.

The deep-seated societal and political notions relating to children as 'innocents' are also reflected in the views and decision making processes of legal professionals including

\footnotetext{
${ }^{5}$ See note 2 above.
} 
prosecutors and judges. As has been argued in the transitional justice context (e.g. Bouris, 2007), victims of sexual offences who are not without blame tend to lie outside of accepted notions of victimhood. A broader literature has generally highlighted the traditionally aggressive stance of defence lawyers in cases of rape or sexual assault where victims who are not perceived as entirely respectable are blamed or seen as 'asking for it' (Temkin, 2000: 229-36; Temkin and Krahé, 2008:41-48). In a similar vein, those children who do not present as pure or 'completely innocent' (Von Hentig, 1948; Mendelsohn, 1956) are rendered undeserving of the label of victim and consequently denied the validity of their suffering and the full protection of the law.

There are a number of useful case examples which demonstrate the highly moralised discourse of legal actors in relation to 'the most guilty' (Von Hentig, 1948; Mendelsohn, 1956) of child victims of sexual crime. In one case, an 18-year old offender originally sentenced for a sex attack on his nine-year old victim while babysitting her was freed on probation after the judge infamously branded the victim as 'no angel. ${ }^{6}$ More recently, nearly two decades later, the same kind of reproachful comments were made by a prosecutor and a judge about a child victim during mitigation in sentencing a 41-year old man for sexual offences against a 13-year old girl. Both had labelled the girl as 'predatory' as the victim had approached the offender in the street and was invited back to his house on a subsequent occasion where the sexual offence took place. ${ }^{7}$ These cases highlight the institutional and cultural entrenchment of stereotypes surrounding the 'ideal victim' of 'real child abuse' young, pure, passive and blameless - and their place at the top of the victim hierarchy. They

\footnotetext{
${ }^{6} \mathrm{H}$. Mills, 'No angel' sex abuse case man jailed: Court of Appeal criticises judge for his unacceptable comment about girl, nine', The Independent, 30 July 1993.

7 'Inquiries launched into "predatory" victim comments', Channel 4 News, 7 August, 2013 http://www.channel4.com/news/sex-abuse-victim-predator-court-paedophile-sentence.
} 
also represent a useful example of 'victim blaming' and the circumstances in which blaming biases may occur.

In such instances, the blameless-blame dichotomy which normally attaches to child victims and adult perpetrators would appear to be reversed as is the master status of victim/perpetrator. This results in the 'overresponsibility' of victims and the 'underresponsibility' of offenders (Lamb, 1996: 95). Children are instead condemned and held responsible as precipitators of their own victimisation (Wolfgang, 1958) thereby diluting the culpability and blameworthiness of the offender. As Furedi has argued, 'the intense moralisation of childhood is fuelled by the imperative to meet society's need for clarity about the constitution of good and evil' (2013: 45). Such examples underline the tension between 'perceptions of children as "at risk" and as potentially threatening' (Scott et al, 1998: 689) where children's own behaviour would appear to threaten the moral order by transversing the innocent/guilt divide and fusing the hitherto sharp juxtaposition of good and evil. They also reflect what Scott and colleagues (1998) have referred to as the 'sexualisation of risk' - the degree of public and political concern expressed whenever the sexual 'innocence' of children is thought to be endangered.

Aside from the oppositional nature of the blaming process, the other interesting dimension of these discourses relates to the complexities of the victim/offender divide. Within the hierarchy of blame, the question of the innocence and blameworthiness of the victim also assumes the distinct and dichotomous nature of sexual victimisation and offending and the linear and one-dimensional relationships between victims and offenders. While criminal justice and transitional justice discourses are heavily premised on the designation of 'victims' or 'perpetrators' as 'reified and distinct' categories (McEvoy and McConnachie, 2012: 527, 
citing Borer, 2003), such neat categorisations are not always possible. In relation to sexual offending, the common depiction of victimhood as being synonymous with innocence and complete blamelessness does not always accord with the realities of lived experience (Aersten, 2011: 206), where the victim may themselves have engaged in sexually harmful behaviour or been complicit in facilitating further offending. It is axiomatic that in most instances of child sexual abuse the victim will be entirely blameless. It is 'deviant' victims (Karmen, 1983), however, who may move between being a 'victim' and becoming a 'victimiser' who present as 'troublesome' (McEvoy and McConnachie, 2013).

While research shows that childhood sexual victimisation is a strong predictor of becoming an adult perpetrator of sexual offending ${ }^{8}$, not all victims progress to becoming offenders themselves. Nonetheless, there a range of useful examples which blur the boundaries between these core categories. Within the context of the internet and on-line sexual exploitation, children may be 'groomed' into procuring other children for offenders for the purposes of producing child pornography (O'Connell, 2003: 11; Palmer and Stacey, 2004: 23). As O'Connell (2003: 4) notes, in such instances, the child technically could be said to be both the producer and distributer of child pornography. When offending occurs on a mass or organised level such complexities concerning what I would term 'a continuum of offending' are even more manifest. Research on historic institutional abuse highlights how some child victims report being abused by their peers as well as adult offenders where abuse has become part of the organisational culture (McAlinden, 2012b: 182). Similarly, 'localised' or 'street grooming', whereby young girls are recruited into 'organised/networked sexual exploitation

\footnotetext{
${ }^{8}$ See e.g. Craissati et al's (2002) who reported that almost half of those convicted of sexual offending against children had been abused as children. See also Hackett et al's (2013) study of 700 young sexual abusers which reports similar percentages.
} 
or trafficking' (Barnardo's, 2011: 6), may also involve young people 'recruiting' other children and young people into exploitative situations.

For victims and offenders of sexual offences concerning children, however, the blameblameless dichotomy would appear to be couched in oversimplistic and absolute terms leaving no room for 'degrees of blame.' These forms of sexual offending concerning children are only beginning to feature on the policy agenda and have traditionally posed unique challenges for law enforcement in terms of victim credibility (Pearce, 2009; McAlinden, 2012a: 213-21). There are a number of factors which dilute the moral positioning and vulnerability of such victims as 'sexual innocents', placing them at the bottom of the victim hierarchy. These include in particular the fact that many victims of internet offending or 'street grooming' are typically older children or adolescents (Finkelhor et al, 2000; CEOP, 2011), who may have become involved in some sort of 'relationship' with their abusers, and who are perceived as having been in some way instrumental in their own abuse and that of others. While care needs to be taken to avoid what Lamb (1996: 8) refers to as 'the overpurification of victims', there is a need for a more nuanced appreciation of degrees of blame and in particular the tension between victim agency/responsibility and coercion (Hoyle et al, 2011) - an argument to which I shall return in the final section.

\section{Offenders, Hierarchies and Blame}

While the literature establishes that there is a 'hierarchy of victimhood' (Carrabine et al, 2004), there is also a related 'hierarchy of offending.' The 'ideal' or archetypal offender who is placed at the top of the offending hierarchy is grounded in the parallel notions of evil, guilt and their deserving of contempt. Within offender ideology 'the paedophile symbolises the antithesis of the sacred child' (Furedi, 2013: 40). While the legitimate or deserving victim of 
child sexual abuse is predicated on the veneration of the sanctity of childhood, this is matched with 'a universal loathing for the child abuser' (Furedi, 2013: 45) and the visualisation of child sexual abuse as 'the supreme evil of our age' (Webster, 1998: 39).

Narrowly framed identities of sex offenders against children have also assumed the mantle of cultural and political status in which the danger posed by male predatory paedophiles is conflated with the dangers posed by sex offenders as a whole and is deemed to be symptomatic of more generalised dangers to children. Following on from the previous section, key inherent or structural attributes of contemporary constructions of sex offending identities are conversely related to their age, gender, and predatory nature - that is the older adult male who had no prior relationship with their victim. In a parallel of Brewer's (2010) notion of 'public victimhood', such factors could also be subsumed within what could be termed 'public offenderhood' - the dominant and public face of sexual offending is underpinned by a number of core inter-related processes, including the communal nature of the violence perpetrated; wrongdoing committed almost exclusively in public; and the repudiation of any form of offending behaviour which falls outside of these limits as a legitimate form of sexual offending.

It is perhaps the notion of sex offenders as 'outsiders' (Becker, 1963) or 'other' (Garland, 2001) which has become the defining characteristic of how and when civil society and polity define and label individuals as sex offenders. The media propagate the 'othering' process by perpetuating the notion that sexual crime is committed by 'fiends', 'beasts' or 'evil monsters', as opposed to 'ordinary' men (Soothill and Walby, 1991; Kitzinger, 1999) and that such acts are "“random", wanton and the intentional acts of evil folk' (Stanko and Lee, 2003:10). Wardle (2007), for example, notes how media depictions of sex offenders are 
often distorted by the deliberate choice of particular photographs, as well as captions. She contends that such techniques are used "to make the "other" appear particularly immoral, bizarre, subhuman, and sexual' (Wardle, 2007: 273). In particular, the 'otherness' of offenders is commonly juxtaposed with the 'ordinariness' of victims in order to affirm membership of these categories.

Returning to the Soham or Sarah Payne cases as examples, the child victim is repeatedly depicted visually in their matching football shirts or school uniform which becomes 'deeply embedded in the popular imagination' (Greer, 2007: 31). These images become an iconic and resounding symbol of the loss of innocence and of the triumph of 'evil' over 'good.' As Wardle argues, the prevalence of such images helps to reinforce social boundaries between childhood and adulthood, as well as those between the law-abiding and the most deviant in society (Wardle, 2007: 280). The notion of sex offenders as 'pure evil' remains a powerful notion in advanced Western societies (Baumeiser, 1996, cited in Wardle, 2007). While victims of child sexual abuse may be subject to 'over purification' (Lamb, 1996: 8), offenders are subject to an oppositional moralising discourse which is premised on the social acceptance of 'evil' as the explanation for such crimes. Such discourses, however, leave little room or tolerance for attempts to contextualise sexual offending (Wardle, 2007), to differentiate between levels and types of risks and fail to take account of 'the humaneness of the perpetrator' (van Roermund, 2001, cited in Henham, 2004: 50).

As feminist commentators have contended, the casting of the sex offender as a sub-human and malevolent stranger helps to maintain the public-private divide and the dichotomy of 'normal' and 'deviant' men by assuming a 'hegemonic masculinity' and a minimalist version of sexualised risks to women and children (Cowburn and Dominelli, 2001; see also Newburn 
and Stanko, 1994). The generalized construction of the 'paedophile' as the dangerous male stranger ignores the family as a site of danger (Saraga, 2001) where women and children are much more vulnerable to abuse at the hands of men well known to them. ${ }^{9}$ However, the fact child sex offenders may be 'of us' rather than 'other than us' is a deeply unpalatable truth for society to countenance. This is because it challenges, as Rock (1998: 185) puts it, our 'moral identities' and represents a complete mismatch with our 'strong, antagonistic archetypes of victim and offender.' It also undermines an idealized version of the sanctity of the family as the traditional sphere of safety and protection where the threat to children's innocence is instead visualised 'as coming from somewhere beyond the boundaries' (Lynch, 2002: 560).

The cultural power of the 'othering' has also shaped legal and policy discourses concerning sexual offending against children. Drawing on the work of the political and legal theorist Agamben, Spencer (2009) conceives of the sex offender as a 'homo sacer' - a non-citizen or bare life without normal citizenry rights and outside the protection of the law - to explain the violence and abjection of sex offenders in western societies. The sex offender as homosacer embodies the opposite of that which is considered sacred because they have defiled the innocence of children and are therefore worthy of expulsion. According to this view, while victims of sexual crime are 'constituted as the subjects of democractic polity', the sex offender is an aberration - a 'completely depraved' subject beyond redemption (Spencer, 2009: 219-20; see also Simon, 1998).

The recent regulatory measures enacted in the United Kingdom and elsewhere to restrict the movement and whereabouts of sex offenders in the community are broadly exclusionary in nature, based around incapacitation, targeted surveillance and situational crime control

\footnotetext{
${ }^{9}$ Research has established that approximately four-fifths of children and women are abused by those well known to them (See Grubin, 1998; Coleman et al, 2007).
} 
(McAlinden, 2012a). For example, the flavour and tenor of the Hansard debates during the passage of the Sexual Offence Act 2003 indicates a highly pathologized discourse concerning the need to protect children from 'the wicked and appalling activities of predatory sexual offenders. $^{10}$ Moreover, there is also a discernible readiness to dispense with the rule of law in the name of the protection of innocence:

Sex offenders have always found ways of gaining the trust and confidence of children.... Deceit is their stock in trade.... Liberty has raised the concern that restrictions will be placed on people displaying inappropriate sexual behaviour before an offence is committed.... but that has to be balanced by protecting the child before actual sexual activity takes place. ${ }^{11}$

Similarly, in her analysis of legislative Federal debates in the United States, Lynch (2002) discerns a moralising legislative and policy discourse which is bolstered with concerns about boundary vulnerabilities between the 'pure' and 'dangerous' social spheres. The imagery projected from these debates is the fear of contamination from a malevolent, toxic supernaturally dangerous outsider 'who creeps and seeps with an incredible knack for invading the pure space of his prey' (Lynch, 2002: 545). Such policies are also heavily predicated on the notion that the risks posed to children reside largely in the public sphere where they can be readily directed and controlled.

As Spencer (2009: 230) contends, in this context, the imposition of regulatory measures has a multi-purpose, serving as 'both a punishment for the defilement of the sacred, for the sake of restoration of order, and the maintenance of the sacred.' In what I would term 'a politics of purification', state sanctioned punishment sustains populist notions of the victim/offender divide by reinforcing the sanctity of childhood and the profanity of the offender. While in most senses this is symbolic only, this use of sovereign power finds its purest expression in the use of castration which both literally and symbolically becomes a purification ritual of the

\footnotetext{
${ }^{10}$ Sexual Offences Bill [HL]: Mr Dawson, Hansard, HL Debs, col 371 (14 $4^{\text {th }}$ October 2003).

${ }^{11}$ Sexual Offences Bill [HL]: Baroness Gould, Hansard, HL Debs, col 786 (13 February 2003).
} 
nefarious sex offender (Spencer, 2009: 232). At the same time, the enactment of these laws brings a sense of reassurance to the community that by targeting a few iniquitous individuals and expunging them from society, evil has been contained and the sanctity of childhood and the family are thereby protected. As discussed below, the 'individualising of responsibility' (McEvoy and McConnachie, 2013) only on to predatory sex offenders, however, also allows society to obfuscate any culpability as 'bystanders' in failing to protect children.

In this respect, a cursory analysis of the ongoing investigation into the crimes of the late Jimmy Savile and a string of other suspected sex offenders as part of Operation Yewtree provides some useful insights into the 'othering process' and the broader processes of blame allocation at the societal, political and institutional levels. Furedi (2013: 2) charts the 'moral crusade' surrounding Savile's transformation from 'celebrity-saint' to the cultural exemplar of the personification of evil. The public and political furore surrounding the Savile case and the unprecedented scale of his abuses served to sustain and reproduce 'a narrative of evil' (Furedi, 2013: 8) couched around social stereotypes about predatory sex offenders and vulnerable child victims. However, it was Savile's status and position within the BBC and his celebrity status within wider society which afforded him access to victims and insulated him from allegations of wrongdoing allowing his behaviour to go unchallenged for decades. As Girard (1989: 82, 87) has argued, part of the function of 'scape-goating' is to shift the blame to 'others' thereby absolving 'us' of any remnants of guilt or responsibility. The individualisation of 'innocence' and 'blame' as attached to particular victims and offenders is therefore also inextricably bound up with the broader processes of social, cultural, political and institutional denial (Cohen, 2001) about the complicity and culpability of such entities (society, popular culture, politics, and institutions) as 'onlookers.' 
The predominance of the adult male stranger as the structuring principle of public and political discourses on child sexual abuse also ignores the gendered and age-related dimensions of sexual offending. Cultural perceptions of the vulnerability and passivity of children and women, their assumed innocence and lack of agency, may negate public and professional concerns about their culpability as perpetrators of sexual offending concerning children (Hetherton, 1999; Denov, 2004). Indeed, both of these groups are typically placed at the bottom of the offending hierarchy due principally to their cultural status as victims. Despite a growing academic interest in young sexual abusers (Erooga and Masson, 2006; Hackett et al, 2013) and female sexual offenders (Gannon et al, 2008; Ashfield et al, 2010) social, policy and broad professional awareness lags someway behind. There are, for example, fewer specialised treatment programmes for young or female abusers, despite the fact that women and children account for a growing proportion of those who offend against children. $^{12}$ As noted above the prevalence and range of sexual exploitation and abuse by as well as among children and young people is an area of growing concern. This includes, for example, 'cyber bullying' (Koefed and Ringrose, 2011), 'sexting' (Ringrose et al, 2012), and 'peer-to-peer grooming', both in on-line (Finkelhor et al, 2000) as well as face-to-face contexts (McAlinden, 2012b).

Public perceptions of female sex offenders in particular are firmly linked to high profile cases involving serious sexual abuse or murder of children, including Myra Hindley as one of the Moors Murderers and most recently Vanessa George and the Little Ted's Nursery case in 2010. Such cultural and gender bias, however, in terms of the perceived blamelessness of women would appear to subvert the innocence-blame bifurcation which typically attaches to

\footnotetext{
${ }^{12}$ Studies estimate that between one-quarter and one-third of all reported cases of child sexual abuse are committed by those under eighteen (Masson and Morrison, 1999). The number of female offenders remains low, typically fewer than five per cent (Cortoni and Hanson, 2005), although anecdotal evidence would place this figure slightly higher.
} 
child victims and adult perpetrators of sexual crime with serious consequences for child protection. That is, women may face less external inhibitors which may otherwise thwart their opportunity to offend (Finkelhor, 1984) because people do not question their motivations or behaviours (McAlinden, 2012b: 138). Similarly, child victims may face enhanced obstacles to disclosing victimization by females because the social perception of safety surrounding women means that the child is less likely to be believed and conversely more likely to be blamed for making false accusations (McAlinden, 2012b: 138). It therefore takes extreme forms of offending for women and children to transgress the normative boundaries attached to their age or gender and reach the top of the offending hierarchy. This also helps to explain public vitriol and official condemnation following high profile cases of violent or sexual offending by children and women. Such crimes are frequently denounced as 'pure evil' or as representing 'the loss of innocence' since they cannot otherwise be reconciled within the deep-seated hierarchies of innocence or blame. ${ }^{13}$

\section{Conclusion}

Bifurcated assumptions about blame in which 'a firm line is traced between the victim and the offender, innocence and guilt, the good and the bad, us and them' (Rock, 1998: 195) underpin much of what we say and do about sex offenders. These oppositional conundrums have informed respective hierarchies of victimhood and offending and shaped populist discourses as well as official priorities concerning child sexual abuse. As Hood (2002:16) has argued in relation to governmentality more broadly, "the outcomes of "blame games" shape the "risk game".' The problem with wanting to see victims as completely pure and offenders

\footnotetext{
${ }^{13}$ See e.g. some of the newspaper headlines on the Bulger, Hindley and George cases: 'The Bulger Murder: An Act of Unparalleled Evil', The Independent, $25^{\text {th }}$ November 1993 (citing Mr Justice Moorhead at the trial of 10- year old Robert Venables and Jon Thompson for the murder of two-year old James Bulger); 'Hindley: A Life of Evil', London Evening Standard, $15^{\text {th }}$ November 2002; 'Vanessa George: One Joint ... The Price on Evil Paedo's Head', Daily Star, $17^{\text {th }}$ December 2009.
} 
as absolutely evil, however, is that few in either group actually fit these expectations (Lamb (1996: 88-89). A key criticism of the 'new penology' (Feeley and Simon, 1992) is that it has produced 'over simplistic accounts of the proliferation of risk as a largely homogeneous and unifying process' (Donoghue, 2013: 805). Rather, as Sparks (2001: 169 has contended, risk is a 'mixed discourse' encompassing 'moral, emotive and political as well as calculative' dimensions. To date, however, moral and emotive aspects have dominated risk-centric discourses helping to sustain stereotypical images about victims and offenders. The moralisation and emotionalisation of discourses on child sexual abuse has tended to impede measured discussion of sexual harm and policies that may actually reduce harm (Cowburn, 2010: 233).

This final section of the article takes up this challenge by arguing for the need to move beyond black and white perceptions of victims and offenders of child sexual abuse and to reframe the politics of risk accordingly. This 'new' discourse could be framed around what feminist commentators prefer as a 'politics of safety' (Stanko, 1990) incorporating strengths and needs based approaches for victims and offenders as well as risk management. I would argue that such discourses must meaningfully consider and engage with the three principal constituencies affected by child sexual abuse: the victim, the offender and the community, and the complex interplay between them. This tripartite focus would take us beyond the victim/offender dichotomy which has been pivotal in shaping contemporary risk-based discourse concerning child sexual abuse. It would shift the emphasis from offender-orientated approaches to incorporate 'victim-orientated' (Donoghue, 2013: 806) as well as communityorientated approaches to risk management. 
The real rather than rhetorical interests of victims need to be put at the forefront of risk-based policies on child sexual abuse. It has been demonstrated that the exercise of voice or agency on the part of victims has been achieved solely through the punishment of offenders (McEvoy and McConnachie, 2012: 527) and by attaching blame to perpetrators, regardless of the actual views of victims themselves (McEvoy and McConnachie, 2012: 530-31, citing Bullimer, 2008). Within this broader context, there are three core assumptions underpinning contemporary victim-centric discourses which deny voice to victims. These relate to victim staticity, homogeneity, and passivity. In relation to the first of these, a retrograde and stagnant snapshot of the victims is co-opted by the state and absorbed by the public wherein a 'frozen' concept of victim is rooted in their pain and suffering and their resulting punitivity. ${ }^{14}$ This stilted notion of victimhood and victim vulnerability, however, does not take account of victim resilience (Walklate, 2011: 184) and the fact that many survivors with counselling and support may recover and overcome the trauma of sexual victimisation. In relation to the second element, current public discourses appear to assume that all victims of sexual crime would pursue or endorse retributive ends with offenders. Not all victims of sexual abuse, however, want to see the offender punished or vilified (Sauzier, 1989; Berliner and Conte, 1995). Many victims of intra-familial abuse in particular may wish to continue contact with the abuser and simply want the abuse to stop. As regards the third element, public and official understanding of victimhood concerning child sexual abuse is rooted in victim passivity as a key predicator of legitimate victim status. This conception of 'victim', however, cannot accommodate 'deviant' child victims who may have been coerced into acquiescing to their own abuse and that of others.

\footnotetext{
${ }^{14}$ I am grateful to Professor Kieran McEvoy for making this point during presentation of an early draft of the paper at a brown bag staff seminar at Queen's University Belfast (March 2013).
} 
Addressing these elements involves front-loading risk management and developing more proactive responses to risks in which the victim's voice and lived experience are made central to defining and responding to child sexual exploitation and abuse. As regards the first two elements outlined above, this could include, for example, a range of support services for vulnerable children and families, for victims and families affected by child sexual abuse, as well as programmes for the non-abusing family members in the case of intra-familial abuse. As discussed further below, it could also include a range of less punitive forms of justice such as restorative programmes with intimate violence and abuse (Mills, 2003; McAlinden, 2007). While critics have noted the latent element of 'compulsory compassion' (Acorn, 1995) within restorative justice in pressurising victims to feel sympathy or responsibility for offender shaming or reintegration, such concerns can be alleviated by operating schemes on a voluntary and carefully selected basis, by supporting victims and by adhering closely to restorative principles (McAlinden, 2007). Moreover, empowering victims also involves educating legal professionals (police, lawyers and judges), about the harmful effects of 'grooming' as well as abuse (McAlinden, 2013b: 268-70) which may affect the victim's own perception of their victimhood as well as how they present to others.

In relation to offenders, exclusionary measures put in place to manage known sex offenders in the community reinforce the 'us-them' boundary. In this sense, the sex offender is a 'double outsider' - physically excluded from the community and also not seen as of the community (Spencer, 2009: 225). As McEvoy and McConnachie (2013) have contended in the context of post-conflict societies, in affording victims voice and agency, there is also a need to acknowledge the rights and humanity of the 'other.' In naming child sexual abuse as 'evil' we need to distinguish the perpetrator from the act (Lamb, 1996: 81-87) and recognise the wickedness of child sexual abuse rather than the abuser themselves. This also accords 
with Braithwaite's (1989: 100-01) notion of 'reintegrative shaming' wherein social condemnation is directed at the evil of the act rather than the evil of the person within a general context of social inclusion and reintegration.

Government funded development of reintegrative measures such as circles of support and accountability, beyond the current ad hoc initiatives, should be considered as a means of managing offender risk, protecting potential victims and engaging the community in wider debates about sex offending (McAlinden, 2007). The 'othering' of sex offenders and the concentration of resources on known sex offenders minimises the risks to children from within both public and private settings where risk may remain unknown. As Cowburn and Dominelli (2001: 400, 404) have contended, the notion of 'stranger danger' calls for a scientific paradigm of risk assessment and management which promotes the false expectation that community safety can be achieved by ever more sophisticated risk management technologies. Formally recognising the humanity of offenders as 'of us' rather than 'other than us' is vitally important, therefore, in making policy makers and society fully cognisant of a wider range of potential risks to children including those from women and children as well as those from within the family and home.

Regarding the community, society's stance as 'onlookers' (Lamb, 1996: 88-127) has helped to entrench cultural notions relating to legitimate victim and offender status. Inadvertently, these may in turn have facilitated further abuse by ensuring the silence of those victims who do not meet the 'real child sexual abuse' stereotype and by masking the activities of those who commit intimate abuse. As noted above, the perpetuation of punitive penal polices on sexual crime are simultaneously based on the belief of offender irredeemability and also help to foster such beliefs (Maruna and King, 2009). Recent studies indicate, however, that the 
public is not as punitive in its attitude towards criminality in general as is traditionally supposed (Roberts et al, 2012). The community, therefore, may have a much larger role in promoting victim and offender resilience than they are afforded at present. Evidence from the evaluation of circles of support has also shown that the public can potentially play a highly significant and constructive role in facilitating offender redemption as well as victim safety (Wilson et al, 2010). As happens in England and Wales, this model can be fashioned in tandem with state processes where the community itself assumes some responsibility for child protection and becomes part of a broader process of bottom-up as well as top-down day-to-day risk management.

A true precautionary approach would balance offender-focused solutions with offencefocused strategies by taking account of the vulnerability of victims as well as the harmful nature of sex offenders. A wider politics or culture of safety concerning 'at-risk' victims (Donoghue, 2013: 807) as well as 'risky' individuals (O’Malley, 2004: 318-9) would comprise mechanisms to address pro-offending behaviour as well as timely intervention with victims. It would also take account of the broader structural contexts in which abuse occurs and offer a means of proactively managing risk within intra-familial as well as extra-familial contexts primarily by encouraging a culture of openness and accountability concerning child sexual abuse. To do otherwise, inevitably means not only increasing regulation and criminalisation, but that we remain fixated with unhelpful discourses on blame and judgmental words such as 'good' and 'evil' with negative consequences for society as well as sex offender management and child protection.

\section{ACKNOWLEDGEMENTS}


I would like to thank my colleagues in the School of Law at Queen's who attended the brown bag seminar at which the outline idea for this paper was presented as well as the two anonymous reviewers for their helpful comments.

\section{REFERENCES}

Acorn, A. (2005), Compulsory Compassion: A Critique of Restorative Justice (Vancouver: University of British Columbia Press).

Aersten, I. (2011), 'Punitivity from a Victim's Perspective', in S. Snacken and E. Dumortier (eds), Resisting Punitiveness in Europe?: Welfare, Human Rights and Democracy (Abingdon, Oxon and New York: Routledge).

Ardau, C. 92004), 'The Perverse Politics of Four-Letter Words: Risk and Pity in the Securitisation of Human Trafficking', Millennium: Journal of International Studies 33(2): 251-77.

Ashfield, S., Brotherston, S., Eldridge, H. and Elliott, I. (2010), 'Working with Female Sexual Offenders: Therapeutic Process Issues' in T.A. Gannon and F. Cortoni (eds). Female Sexual Offenders: Theory, Assessment and Treatment (Chichester: WileyBlackwell).

Ashworth, A. (2000), 'Victims' Rights, Defendants' Rights and Criminal Procedure', in A. Crawford and J. Goodey (eds), Integrating a Victim Perspective within Criminal Justice (Aldershot: Ashgate).

Barnardo's (2011), Puppet on a String: The Urgent Need to Cut Children Free from Sexual Exploitation (Barkingside, Ilford: Barnardos).

Baumeiser, R.F. (1996), Evil: Inside Human Violence and Cruelty (New York: W.H. Freeman). 
Becker, H. (1963), Outsiders: Studies in the Sociology of Deviance (New York: The Free Press of Glencoe).

Berliner, L. and Conte, J.R. (1995), 'The Effects of Disclosure and Intervention on Sexually Abused Children', Child Abuse \& Neglect 19(3): 371-84.

Best, J. (1993), Threatened Children: Rhetoric and Concern about Child-Victims (Chicago: University of Chicago Press).

Bichard, Sir M. (2004), The Bichard Inquiry Report (London: Home Office).

Blanchette, K. and Taylor, K.N. (2010), 'A Review of Treatment Initiatives for Female Sexual Offenders, in T. A. Gannon and F. Cortoni (eds.), Female Sexual Offenders: Theory, Assessment and Treatment (Chichester: John Wiley \& Sons, Ltd.).

Borer, T.A. (2003), 'A Taxonomy of Victims and Perpetrators: Human Rights and Reconciliation in South Africa', Human Rights Quarterly 25(4): 1088-116.

Bouris, E. (2007), Complex Political Victimhood (Bloomfield, CT: Kumarian Press.

Braithwaite, J. (1989), Crime, Shame and Reintegration. Sydney: Cambridge University Press.

Brewer, J. (2010), Peace Processes: A Sociological Approach (Cambridge: Polity Press).

Bullimer, K. (2008), In An Abusive State: How Neo-Loiberalism Appropriated the Feminist Movement Against Sexual Violence (Durham, NC: Duke University Press).

Carrabine, E., Inganski, P. Lee, M., Plummer, K. and South, N. (2004), Criminology: A Sociological Introduction (London: Routledge).

Child Exploitation and Online Protection Centre (CEOP) (2011), Out of Mind, Out of Sight. Breaking Down the Barriers to Understanding Child Sexual Exploitation (London: CEOP), at http://ceop.police.uk/Documents/ceopdocs/ceop_thematic_assessment_executive_sum mary.pdf (accessed on $28^{\text {th }}$ May 2013). 
Christie, C. (1986), 'The Ideal Victim', in E. Fattah (ed.), From Crime Policy to Victim Policy (Basingstoke: Macmillan).

Cohen, S. (2001), States of Denial: Knowing About Atrocities and Suffering (Cambridge: Polity Press).

Coleman, K., Jansson, K., Kaiza, P. and Reed, E. (2007), Homicide, Firearm Offences and Intimate Violence 2005/2006 (Supplementary Volume 1 to Crime in England and Wales 2005/2006) (accessed $26^{\text {th }}$ February 2013):

http://webarchive.nationalarchives.gov.uk/20110220105210/rds.homeoffice.gov.uk/rds/ pdfs07/hosb0207.pdf

Cortoni, F. and Hanson, R.K. (2005), A Review of the Recidivism Rates of Adult Female Sexual Offenders, Research Report No R-169 (Ottawa, Ontario: Correctional Service of Canada).

Cowburn, M. (2010), 'Invisible Men: Social Reactions to Male Sexual Coercion - Bringing Men and Masculinities into Community Safety and Public Policy', Critical Social Policy 30(2) 225-44.

Cowburn, M. and Dominelli, L. (2001), 'Making Hegemonic Masculinity: Reconstrcting the Paedophile as the Dangerous Stranger', British Journal of Social Work 31(3): 399415.

Craissati, J., McClurg, G. and Browne, K. (2002), 'Characteristics of Perpetrators of Child SexualAbuse Who Have Been Sexually Victimized as Children', Sexual Abuse: A Journal of Research and Treatment 14(3): 21-35.

Crawford, A. (2003), 'Contractual Governance of Deviant Behaviour', Journal of Law and Society 30(4): 479-505.

De Haan, W. and Loader, I. (2002), 'On the Emotions of Crime, Punishment and Social Control', Theoretical Criminology, 6(3): 243-254. 
Denov, M. (2004), Perspectives on Female Sex Offending: A Culture of Denial (Hampshire: Ashgate Publishing).

Donoghue, J. (2013), 'Reflection on Risk, Anti-Social Behaviour and Vulnerable/Repeat Victim', British Journal of Criminology 53(5): 805-23.

Dubber, M.D. (2006), Victims in the War on Crime: The Use and Abuse of Victims' Rights (New York: New York University Press).

Elias, R. (1993), Victims Still: The Political Manipulation of Crime Victims (London: Sage).

Elliott. M., Browne, K. and Kilcoyne, J. (1995), 'Child Abuse Prevention: What Offenders Tell us', Child Abuse and Neglect 19(5): 579-94.

Ericson, R. (2007), Crime in an Insecure World (Cambridge: Polity Press).

Erooga, M. and Masson, H. (2006), Children and Young People who Sexually Abuse Others: Current Developments and Practice Responses ( $2^{\text {nd }}$ edn) (London: Routledge).

Feeley, M. and Simon, J. (1992), 'The New Penology: Notes on the Emerging Strategy of Corrections and Its Implications', Criminology, 30(4): 449-474.

Finkelhor, D. (1984), Child Sexual Abuse: New Theory and Research (New York: The Free Press).

Finkelhor, D., Mitchell, K.J. and Wolak, J. (2000), Online Vicimization: A Report on the Nation's Youth (Alexandria, VA: National Center for Missing and Exploited Children), at http://www.unh.edu/ccrc/pdf/Victimization_Online_Survey.pdf $\quad$ (accessed $26^{\text {th }}$ February 2013).

Furedi, F. (2013), Moral Crusades in An Age of Mistrust: The Jimmy Savile Scandal (Basingstoke: Palgrave Macmillan). 
Gannon, T.A., Rose, M.R. and Ward, T. (2008), 'A Descriptive Model of the Offense Process for Female Sexual Offenders', Sexual Abuse: A Journal of Research and Treatment 203/: 352-74.

Garland, D. (2001), The Culture of Control: Crime and Social Order in Contemporary Society (Oxford: Oxford University Press).

Girard, R. (1989), The Scapegoat (repr) (Baltimore, MD: John Hopkins University Press).

Greer, C. (2007), 'News Media, Victims and Crime', in P. Davies, P. Francis and C. Greer (eds), Victims, Crime and Society (London: Sage).

Grubin, D. (1998), Sex Offending Against Children: Understanding the Risk, Police Research Series Paper 99 (London: Home Office).

Hackett, S., Masson, H., Balfe, M. and Phillips, J. (2013), 'Individual, Family and Abuse Characteristics of 700 British Child and Adolescent Sexual Abusers', Child Abuse Review, ISSN 0952-9136 (In Press).

Hacking, I. (2003), 'Risk and Dirt' in R. Ericson and A.Doyle (eds), Risk and Morality (Toronto: University of Toronto Press).

Hebenton, B. and Seddon, T. (2009), 'From Dangerousness to Precaution: Managing Sexual and Violent Offenders in an Insecure and Uncertain Age', British Journal of Criminology 49(3): 343-62.

Henham, R. (2004), 'Conceptualizing Access to Justice and Victims' Rights in International Sentencing', Social and Legal Studies 13(1): 27-55.

Hetherton, J. (1999), 'The Idealisation of Women: Its Role in the Minimisation of Child Sexual Abuse by Females', Child Abuse and Neglect 23/2: 161-74.

Holstein, J.A. an Miller, G. (1990), 'Rethinking Victimisation: An Interactional Approach to Victimology', Holstein, J.A. an Miller, G. (1990), 'Rethinking Victimisation: An Interactional Approach to Victimology', Symbolic Interaction 13(1): 103-22. 
Hood, C. 'The Risk Game and the Blame Game', Government and Opposition 37(1):15-37.

Hoyle, C., Bosworth, M. and Dempsey, M. (2011), 'Labelling the Victims of Sex Trafficking: Exploring the Borderland Between Rhetoric and Reality', Social and Legal Studies, 20(3): 313-29.

Hunt, A. (2011), 'Moral Panics and Moral Regulation' in S. Hier (ed), Moral Panic and the Politics of Anxiety (London: Routledge).

Innes, M. (2004), 'Signal Crimes and Signal Disorders: Notes on Deviance as Communicative Action', British Journal of Sociology 55(3): 335-55.

Jacobsson, K. and Löfmarck, E. (2008), 'A Sociology of Scandal and Moral Transgression: The Swedish "Nannygate” Scandal', Acta Sociologica 51(3): 203-16.

Karmen, A. (1983), 'Introduction: Deviance and Victimology', in D. MacNamara and A. Karmen (eds), Deviants: Victims or Victimizers (Beverly Hills, CA: Sage).

Karstedt, S. (2002), 'Emotions and Criminal Justice', Theoretical Criminology, 6(3): 299318.

Kemshall, H. and Maguire, M. (2001), 'Public Protection, Partnership and Risk Penalty: The Multi-agency Risk Management of Sexual and Violent Offenders', Punishment and Society 3(2): 237-64.

Kitzinger, J. (1999), 'The Ultimate Neighbour from Hell: Media Framing of Paedophiles', in B. Franklin (ed), Social Policy, the Media and Misrepresentation (London: Routledge).

Koefed, J. and Ringrose, J. (2011) Travelling and Sticky Affects: Exploring Teens and Sexualized Cyberbullying through a Butlerian-Deleuzian-Guattarian Lens', Discourse: Studies in the Cultural Politics of Education 33/1:5-20.

Lamb, S. (1996), The Trouble with Blame: Victims, Perpetrators and Responsibility (Cambridge, Mass: Harvard University Press. 
Loader, I. and Walker, N. (2007), Civilizing Security (Cambridge: Cambridge University Press).

Lynch, M. (2002), 'Pedophiles and Cyber-Predators as Contaminating Forces: The Language of Disgust, Pollution, and Boundary Invasions in Federal Debates on Sex Offender Legislation', Law \& Social Inquity 2793): 529-66.

Madlingozi, T. (2007), 'Good Victims, Bad Victims: Apartheid's Beneficiaries, Victims and the Struggle for Social Justice', in W. Le Roux amd L Van Maerle (eds), Memory and the Legacy of Apartheid (Pretoria: Pretoria University Press).

Maruna, S. and King, A. (2009), 'Once a Criminal Always a Criminal?: "Redeemability” and the Psychology of Punitive Public Attitudes', European Journal of Criminal Policy and Research, 15(1/2): 7-14.

Masson, H. and Morrison, T. (1999), 'Young Sexual Abusers: Conceptual Frameworks, Issues and Imperatives', Children and Society, 13(3): 203-15.

Mawby, R. and Walklate, S. (1994), Critical Victimology: International Perspectives (London: Sage Publications Ltd).

McAlinden, A. (2007), The Shaming of Sexual Offenders: Risk, Retribution and Reintegration (Oxford: Hart Publishing)

-- (2010), 'Vetting Sexual Offenders: State Over-extension, the Punishment Deficit and the Failure to Manage Risk', Social \& Legal Studies 19(1): 25-48.

-- (2012a), 'The Governance of Sexual Offending Across Europe: Penal Policies, Political Economies and the Institutionalisation of Risk', Punishment and Society 14(2): 166-92. -- (2012b), 'Grooming' and the Sexual Abuse of Children: Institutional, Internet and Familial Dimensions, Clarendon Studies in Criminology (Oxford: Oxford University Press).

McEvoy, K. and McConnachie, K. (2012), 'Victimology in Transitional Justice: Victimhood, Innocence and Hierarchy', European Journal of Criminology 9(5): 527-38. 
McEvoy, K. (2013), 'Victims in Transition: Voice, Agency and Blame in Post-Conflict Societies', Social and Legal Studies (in press).

Mendelsohn, B. (1956), 'Une Nouvelle Branche de La Science Bio-Psycho-Sociale: Victimologie', Revue Internationale de Criminologie et de Police Technique' 10: 78289.

Merleau-Ponty, M. (1973), The Prose of the World (Evanston: Northwestern University Press).

Mills, LG (2003) Insult to Injury: Rethinking Our Responses to Intimate Abuse (Princeton, Princeton University Press).

Morgan, J. and Zedner, L. (1992), Child Victims. Oxford: Clarendon Press.

Newburn, T. and Stanko, E.A. (eds) (1994), Just Boys Doing Business? Men, Masculinities and Crime (London: Routledge).

O'Connell, R. (2003), A Typology of Child Cybersexploitation and Online Grooming Practices, at http://image.guardian.co.uk/sysfiles/Society/documents/2003/07/24/Netpaedoreport.pdf (accessed $26^{\text {th }}$ February 2013).

O’Malley, P. (2004), 'The Uncertain Promise of Risk', Australian \& New Zealand Journal of Criminology 37(3): 323-43.

Palmer, T. and Stacey, L. (2004), Just One Click: Sexual Abuse of Children and Young People through the Internet and Mobile Phone Technology (Barkingside, UK: Barnardo’s).

Pearce, J. (2009), Young People and Sexual Exploitation: It's Not Hidden You Just Aren't Looking (Abingdon, Oxon: Routledge).

Pratt, J. (2000), 'Emotive and Ostentatious Punishment: Its Decline and Resurgence in Modern Society', Punishment and Society 2(4): 417-39. 
Ramsay, P. (2010), 'Overcriminalization as Vulnerable Citizenship', New Criminal Law Review, 13(2): 262-285.

Ringrose, J., Gill. R., Livingstone, S. and Harvey, L. (2012) A Qualitative Study of Children, Young People and 'Sexting', A Report Prepared for the NSPCC, http://www.nspcc.org.uk (accessed $26^{\text {th }}$ February 2013).

Roberts, J., Hough, M., Jackson, J. and Gerber, M.M. (2012), 'Public Opinion Towards the Lay Magistracy and the Sentencing Council Guidelines: The Effects of Information on Attitudes', British Journal of Criminology 52(6): 1072-91.

Rock, P. (1998), 'Murderers, Victims and "Survivors", British Journal of Criminology 38(2): 185-200.

-- (2002), 'On Becoming a Victim', in C. Hoyle and R. Young (eds), New Visions of Crime Victims (Oxford: Hart).

Saraga, E. (2001), 'Dangerous Places: The Family as a Site of Crime', in J. Muncie and E. McLaughlin (eds), The Problem of Crime ( $2^{\text {nd }}$ edn) (London: Sage).

Sauzier, M. (1989), 'Disclosure of Child Sexual Abuse: For Better for Worse', Psychiatric Clinics of North America 12(2): 455-69.

Scott, S., Jacksom, S. and Beckett-Milburn (1998), 'Swings and Roundabouts: Risk Anxiety and the Everyday Worlds of Children', Sociology 32(4): 689-705.

Silverman, J. and Wilson, D. (2002), Innocence Betrayed: Paedophilia, the Media and Society (Cambridge: Polity Press).

Simon, J. (1998), 'Managing the Monstrous: Sex Offenders and the New Penology', Psychology, Public Policy and Law 4(1/2): 452-67.

Soothill, K. and Walby, S. (1991), Sex Crime in the News (London: Routledge).

Sparks, R. (2001), 'Degrees of Estrangement: The Cultural Theory of Risk and Comparative Penology', Theoretical Criminology, 5(2): 159-76. 
Spencer, D. (2009), 'Sex Offender as Homo Sacer', Punishment and Society 11(2): 219-40.

Stanko, E.A. (1990), Everyday Violence (London: Virago).

Stanko, E.A. and Lee, R. (2003), 'Introduction: Methodology Reflections', in R. Lee and E. Stanko (eds), Researching Violence: Essays on Methodology and Measurement (London: Routledge).

Stewart, M.W., Dobbin, S.A. and Gatowski, S.I. (1996), "Real Rapes" and "Real Victims": The Shared Reliance on Common Cultural Definitions of Rape', Feminist Legal Studies 4(2): 159-77.

Temkin, J. (2000), 'Prosecuting and Defending Rape: Perpsectives from the Bar', Journal of Law and Society 27(2): 219-48.

Temkin, J. and Krahé, B. (2008), Sexual Assault and the Justice Gap: A Question of Attitude (Oxford: Hart Publishing).

Tilly, C. (2008), Credit and Blame (Princeton, NJ: Princeton University Press.

Valier, C. (2005), Memorial Laws: Victims, Law and Justice (London: Cavendish).

van Roermund, B.C.J. (2001), 'Rubbing Off and Rubbing On: The Grammar of Reconciliation', in E.A. Christodoulidis and S. Veitch (eds), Lethe's Law (Oxford: Hart Publishing).

Von Hentig, H. (1948), The Criminal and His Victim (New Haven, DT: Yale University Press).

Walklate, S. (2007), Imagining the Victim of Crime (New York: McGraw-Hill).

-- (2011), 'Reframing Criminal Victimization: Finding a Place for Vulnerability an Resilience', Theoretical Criminology 15(2): 179- .

Wardle, C. (2007), 'Monsters and Angels: Visual Press Coverage of Child Murders in the USA and the UK, 1930-2000', Journalism 8 (3): 263-84. 
Weaver, B. and McNeill, F. (2010), 'Public Protection in Scotland: A Way Forward?' in A. Williams and M. Nash (eds), Handbook of Public Protection (Devon: Cullompton, Publishing).

Webster, R. (2005), The Secret of Bryn Estyn: The Making of a Modern Witch Hunt (Oxfor: Orwell Press.

Wilson, C., Bates, A. and Völlm, B. (2010), 'Circles of Support and Accountability: An Innovative Approach to Manage High-Risk Sex Offenders in the Community', The Open Criminology Journal 3: 48-57.

Wolfgang, M. (1958), Patterns in Criminal Homicide (Philadelphia, PA: University of Pennsylvania Press.

Young, J. (2003), 'Merton with Energy, Katz and Structure: The Sociology of Vindictiveness and the Criminology of Transgression', Theoretical Criminology 7(3): 389-414.

Zedner, L. (2002), 'Victims', in M. Maguire, R. Morgan and R. Reiner (eds), The Oxford Handbook of Criminology (3rd edn) (Oxford: Oxford University Press).

-- (2009), Fixing the Future? The Pre-emptive Turn in Criminal Justice', in B. McSherry, A. Norrie and S. Bronitt (eds), Regulating Deviance: The Redirection of Criminalisation and the Futures of Criminal Law (Oxford: Hart Publishing).

Zelizer, V. (1994), Pricing the Priceless Child: The Changing Social Value of Children (Princeton, NJ: Princeton University Press.) 